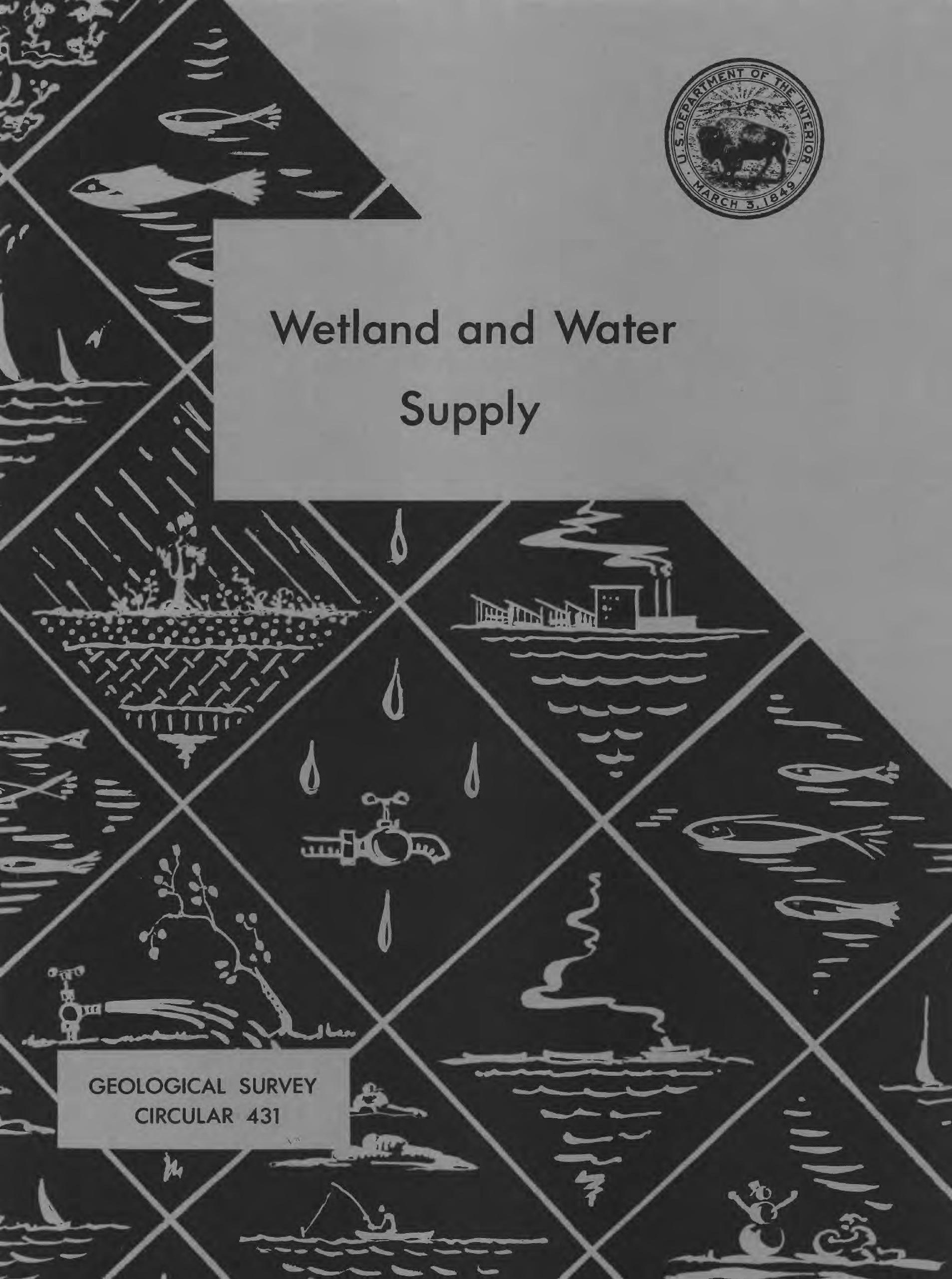




\title{
Wetland and Water Supply
}

\author{
By John A. Baker
}

父

Geological Survey Circular 431 
United States Department of the Interior FRED A. SEATON, SECRETARY

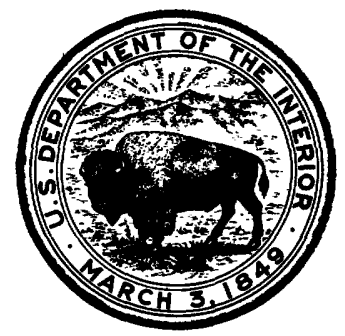

Geological Survey

THOMAS B. NOLAN, DIRECTOR

父

Free on application to the U.S. Geological Survey, Washington 25, D. C. 


\title{
Wetland and Water Supply
}

\author{
By John A. Baker
}

\begin{abstract}
Statement at Northeast Field Committee Meeting-Eastham, Mass., Aug. 5, 1959.

The Geological Survey has received numerous inquiries about the effects of proposed changes in the wetland environment. The nature of the inquiries suggests a general confusion in the public mind as to wetland values and an increasing concern by the public with the need for facts as a basis for sound decisions when public action is required.
\end{abstract}

Perhaps the largest gap in our knowledge is in regard to the role played by the wetland in the natural water scheme. Specialists in such fields as agriculture and conservation have studied the wetland in relation to its special uses and values for farming and as a habitat for fish and wildlife. However, except as studied incidentally by these specialists, the role of the wetland with respect to water has been largely neglected. This facet of the wetland problem is of direct concern to the Geological Survey.

We commonly speak of water in terms of its place in the hydrologic environment-as, for example, surface water or ground water. These terms imply that water can be neatly pigeonholed. With respect to the wetland environment nothing can be further from the truth. In fact, one objective of this discussion is to demonstrate that for the wetland environment surface water, ground water, and soil water cannot be separated realistically, but are closely interrelated and must be studied together. It should be noted that this statement holds true for the hydrologic environment in general, and that the wetland environment is by no means unique in this respect. Our second and principal objective is to identify some of the problems that must be studied in order to clarify the role of the wetland in relation to water supply.
We have chosen to approach these objectives by briefly describing one area for which we have some information, and by using this example to point out some of the problems that need study. First, however, let us define what we, as geohydrologists, mean by wetland and briefly consider wetland classifications.

For our purpose wetlands are land areas that are covered with shallow water or subjected to intermittent flooding and subsequent slow drainage, and which generally are characterized by an accumulation of organic matter hereafter termed "swamp deposits." These wetlands may be classified in a number of different ways depending on the purpose of the classifier. For example, the Fish and Wildlife Service classifies wetlands into 20 different types based on water quality (fresh or salty), drainage, and vegetation. At the risk of some oversimplification we might consider 4 types of wetland from the standpoint of hydrology: (1) fresh-water swamps in which the swamp deposits are underlain by glacial till or bedrock; (2) fresh-water swamps in which the swampdeposits are underlain by marine or lacustrine clay and silt; (3) fresh-water swamps in which the swamp deposits are underlain by glacial outwash or alluvium consisting mostly of sand or sand and gravel; and (4) salt marshes and salt meadows. The three fresh-water types of wetland are of interest with respect to water supply, and of these, the type in which swamp deposits are underlain by glacial outwash is of particular interest in New England.

In the Ipswich River basin above the Geological Survey gaging station at South Middleton, Mass., is an area of 44 square miles which forms the headwaters section of the basin. The relief of the area is low. About half the area consists of hills mostly underlain by bedrock but mantled by a thin layer of 
glacial till. The other half consists of lowlands-including swamps, low terraces and plains-underlain by glacial outwash. Swampland, used hereafter as a synonym for wetland, forms about a fourth of the area. Some of the swamps occupy depressions in the till blanket and are situated at somewhat higher levels than the lowlands. The largest swamps, however, border the Ipswich River and its tributaries. Here the swamp deposits, which consist of muck and peat mixed with some silt and sand, overlie glacial outwash deposits, which consist principally of sand with subordinate amounts of silt, clay, and gravel. The swamp deposits are thin at most places but locally they may be as much as 55 feet thick. The outwash, which occupies the preglacial valley of the Ipswich, is more than 100 feet thick at places over the old buried channel.

The outwash forms an extensive semicontinuous ground-water reservoir. The body of outwash is rather narrow along the main stem of the Ipswich but in the headwaters area it is broad and mantles the lower parts of the preglacial divides between the headwater streams. In general, the more permeable materials in the outwash occur along the margins of the valley where they form terraces and more or less isolated mounds, plains, and ridges. Less permeable materials occupy the deeper parts of the preglacial valleys and overlap or interfinger with the more permeable materials toward the sides of the valleys. These less permeable materials are overlain nearly everywhere by swamp deposits, which form a discontinuous semipermeable cover over about half the area of the ground-water reservoir. Bedrock together with a thin layer of glacial till forms a relatively impermeable floor beneath the outwash. During most of the year the reservoir materials are saturated with water nearly to the land surface.

In this part of the Ipswich basin, the towns of Reading, North Reading, and Wilmington draw their water supplies from wells. Several towns in the lower part of the Ipswich River basin draw water from wells, from ponds, or from the Ipswich River or its tributaries. Also, a number of towns outside the drainage basin draw water from streams or lakes within the basin.

Some wells draw water principally from ground-water storage in their immediate vicinity. Others draw water not only from ground-water storage locally but also induce recharge from nearby streams during part of the year at least. During periods of no direct runoff the flow of these streams consists principally of ground-water runoff and, in effect, wells that induce recharge import water by way of the streams from upstream parts of the ground-water reservoir.

The ground-water reservoir, the swamps, and the streams together form a major watersupply system. To illustrate how this system operates consider a typical water year beginning in October. At this time of the year the surfaces of the swamplands are dry, and the water table stands in the swamp deposits or possibly below them at some places. Streamflow is low and is derived principally from the ground-water reservoir. Vegetation is discharging water from the swamp deposits either from soil-moisture storage or from the ground-water reservoir. With the first killing frost the discharge of water by vegetation is turned off. The first appreciable precipitation thereafter is accompanied by recharge of the ground-water reservoir, a rise in the water table, and an increase in runoff, including an increase in the base flow of the streams. From late fall throughout the winter the water table remains at or near land surface in the swamps. Ponded water is present during most of this time on the swamp surfaces. Perhaps some of this ponded water is a result of precipitation catch, some comes from. streams by overbank flooding, and some may come from upward seepage of ground water derived from the outwash at the periphery of the reservoir. In the spring, the melting snow and the spring rains assure a high wate $r$ table and a fully recharged ground-water reservoir. Water remains ponded on the swamps. The rate of runoff of the Ipswich and its tributaries is high. The growing season begins and progresses. Water is discharged from the swamps to the atmosphere by evaporation and transpiration.

The ground-water reservoir continues to discharge to the streams. There is very little, if any, recharge to the ground-water body. For a time runoff is sustained by swamp storage-that is water temporarily stored on the swamp surfaces-as well as by ground-water runoff. Finally the swamp surfaces dry up and streamflow is sustained principally by ground-water runoff. If the summer is unusually dry the antecedent 
moisture conditions in the swamp soils may generally be unfavorable to direct runoff except after heavy extended rains-and so on to the end of the water year.

This picture is, of course, highly generalized. Nevertheless it shows us that the swamp deposits and the swamp surfaces have a role in the operation of the water system. Swamp surfaces store flood waters. Swamp deposits store water. With respect to the ground-water reservoir, the swamps serve as discharge areas for much of the year, but they may serve as recharge areas occasionally. When the swamp surfaces are dry the moisture conditions in the swamp soils affect the infiltration rate directly and the rate of direct runoff indirectly. Perhaps also the soil-moisture conditions affect the rate of recharge to the ground-water reservoir and the rate of discharge of ground water by evapotranspiration.

We know in general how the water system operates, but the details of operation are vague and poorly defined. Knowledge of these details is essential if people are to manage the water system effectively, and to protect and improve it. Such knowledge also is essential if the effects of changes in the hydrologic environment on the system are to be predicted with assurance.

In considering the details needed it is apparent that we have a problem in which surface water, ground water, and soil water are so intimately associated that they must be studied together. The no man's land of this problem is the swamp environment. With respect to this environment we specifically need to know:

1. The hydrologic properties and physical properties of the swamp deposits under various conditions-for example: when saturated, when dry, at various degrees of wetting, and when intermittently wetted.

2. The infiltration capacity of swamp soils under given sets of conditions.

3. The operation of the swamps and the swamp deposits as a discharge element under given sets of conditions.

4. The operation of the swamps and the swamp deposits as a recharge element under given sets of conditions.

5. The operation of the swamps and the swamp deposits as a storage element under given sets of conditions.

6. The relative contribution of swamp storage and ground water to runoff.

7. The effect of the swamp environment on the chemical quality of the water.

In the foregoing discussion we have given an example of one area in which a wetland plays a role with respect to water supply. We have listed some of the facets of wetland hydrology that need study if this role is to be properly evaluated. In conclusion it is clear that we have much to learn if we are to fill the gap in knowledge that presently exists with respect to the wetland and water supply. 